\title{
PELAKSANAAAN DALAM PENERAPAN K3RS UPAYA PENCEGAHAN PENYAKIT AKIBAT KERJA PADA PERAWAT
}

TATI OKTIANA TAMBA

\section{Tatitamba26@gmail.com}

\section{LATAR BELAKANG}

Rumah sakit adalah sebuah industri jasa tempat penyediaan layanan kesehatan untuk masyarakat. Rumah sakit merupakan salah satu tempat kerja yang berpotensi menimbulkan bahaya. Rumah Sakit harus menjamin kesehatan dan keselamatan baik terhadap pasien, penyediaan layanan atau pekerja maupun masyarakat sekitar dari berbagai potensi bahaya di Rumah Sakit. Pengetahuan kesehatan dan keselamatan kerja (K3) yang baik dapat menurunkan angka kecelakaan kerja hingga tercapainya zero accident.

Perawat merupakan tenaga kesehatan yang sering kontak dengan pasien sehingga diharapkan mampu menerapkan K3 dengan baik. Oleh karena itu, Rumah Sakit dituntut untuk melaksanakan Upaya Kesehatan dan Keselamatan Kerja (K3) yang dilaksanakan secara terintegrasi dan menyeluruh sehingga risiko terjadinya Penyakit Akibat Kerja (PAK) dan Kecelakaan Akibat Kerja (KAK) di Rumah Sakit dapat dihindari. Penyakit akibat kerja di rumah sakit dapat menyerang semua tenaga kerja baik medis maupun non medis.

Dalam Undang-Undang Nomor 36 Tahun 2009 tentang Kesehatan, Pasal 165 : pengelola tempat kerja wajib melakukan segala bentuk upaya kesehatan melalui upaya pencegahan, peningkatan, pengobatan, dan pemulihan bagi tenaga kerja. Berdasarkan pasal tersebut maka pengelola tempat kerja di Rumah Sakit mempunyai kewajiban untuk menyehatkan para tenaga kerjanya. Salah satunya adalah melalui upaya kesehatan kerja disamping keselamatan kerja.

Penerapan K3 di Indonesia diatur oleh UndangUndang Republik Indonesia Nomor 13 Tahun 2003 tentang Ketenagakerjaan, sedangkan K3 rumah sakit (K3RS) diatur oleh KEPMENKES RI Nomor 1087/MENKES/SK/VIII/2010. K3 pada umumnya bertujuan melindungi keselamatan dan kesehatan pekerja ataupun buruh dalam mewujudkan produktivitas kerja yang optimal.21 Tujuan diterapkannya K3RS adalah terciptanya cara kerja, lingkungan kerja yang sehat, aman, 
nyaman, dan dalam rangka meningkatkan derajat kesehatan karyawan RS. Pengetahuan K3RS yang baik diharapkan mampu menekan angka kecelakaan kerja karena individu tersebut dapat menerapkan tindakan yang sesuai dengan pengetahuan K3 yang dimilikinya.

Kecelakaan kerja pada perawat dianggap sebagai suatu masalah serius karena mengancam kesehatan dan kesejahteraan pasien dan petugas kesehatan secara global (Maria, 2015). Kecelakaan tersebut yang pada akhirnya dapat mempengaruhi produktivitas kerja perawat. Produktivitas kerja yang rendah pada akhirnya berdampak terhadap pelayanan kesehatan yang diberikan oleh rumah sakit.

Upaya untuk mencegah kecelakaan kerja adalah dengan menghilangkan risiko atau

mengendalikan sumber bahaya dan usaha yang terakhir adalah mengunakan alat pelindung diri (APD). Pencegahan tersebut lebih diarahkan pada lingkungan kerja, peralatan, dan terutama adalah pekerja.

Tujuan penelitian ini untuk mengetahui pelaksanaan dalam penerapan kesehatan keselamatan kerja di rumah sakit yang dilakukan oleh perawat agar terhindar dari penyakit akibat kerja pada perawat maupun tim medis lainnya.

\section{METODE}

Metode yang digunakan dalam pembahasan dan penulisan ini adalah metode membaca dan literasi data. Dimana dilakukan dengan teknik pengumpulan data atau informasi dengan melakukan analisis, eksplorasi, kajian bebas (literatur review) yang relevan yang berfokus pada tema yaitu upaya pencegahan penyakit akibat kerja pada perawat.

Adapun sumber yang digunakan dalam penulisan ini menggunakan sumber dari 10 jurnal dengan memasukkan referensi kunci upaya pencegahan penyakit akibat kerja pada perawat yang telah ditentukan. Adapun referensi dari jurnal yang saya gunakan merupakan jurnal yang diterbitkan pada 8 tahun terakhir (dengan tahun paling tua 2012). 


\section{HASIL}

Berdasarkan hasil analisis dan kajian bebas dari beberapa jurnal yang sesuai dengan topik yang di bahas.Maka dapat diperoleh bahwa pemicu penyakit karena kerja yang dapat menyebabkan penyakit akibat kerja (PAK) pada perawat yang terjadi di Rumah Sakit (RS), umumnya berkaitan dengan:

\section{1.faktor biologi}

2. faktor kimia

3.faktor ergonomi

4.faktor fisik dalam dosis kecil yang terus menerus

\section{5.faktor psikologis}

Setiap rumah sakit harus memiliki sistem manajemen K3RS Yang meliputi penetapan dalam kebijakan K3RS, perencanaan K3RS, pelaksanaan rencana K3RS, pemantauan dan evaluasi K3RS, serta peninjauan dan peningkatan kinerja K3RS. Pembentukan tim K3RS merupakan bukti bahwa pihak rumah sakit telah memiliki komitmen untuk meneraspkan K3 di rumah sakit dan merupakan kewajiban rumah sakit dalam memenuhi tuntutan pemerintah untuk mengadakan keselamatan dan kesehatan kerja.Namun dalam kenyataaan bahwa tim K3 belum melaksanakan tugasnya secara maksimal. Rumah sakit juga melaksanakan manajemen risiko, kegiatan yang dilakukan untuk menentukan tanggung jawab SDM rumah sakit, menentukan ruang lingkup manajemen risiko $\mathrm{K} 3$, menetukan aktivitas, proses, fungsi, pelayanan, dan asset rumah sakit.

\section{Upaya pencegahan menurut standar K3 yaitu:}

1. Melakukan pencatatan kejadian Kecelakaan Akibat Kerja (KAK) sesuai dengan prosedur yang ditetapkan oleh petugas K3

2. Perlu dilakukan peningkatan terhadap penerapan pelayanan kesehatan kerja terutama pada pemeriksaan kesehatan khusus, pengobatan dan perawatan bagi penderita yang sakit, pemantauan lingkungan kerja serta ergonomi dan evaluasi pencatatan serta pelaporan kepada Direktur Rumah Sakit. 
3. Perlu diadakan pemeriksaan kesehatan sebelum bekerja seperti pemeriksaan paru-paru, laboratorium maupun pemeriksaan secara fisik terhadap perawat IGD maupun tenaga medis yang lain.

4. Perlu diadakan kegiatansurvelans kerja seperti pemetaan tempat keja berdasarkan risiko bahayanya.

5. Perlu diadakan penyesuaian terhadap peralatan kerja SDM Rumah Sakit seperti mengidentifikasi ergonomi terhadap peralatan kerja dan risiko peralatan kerjanya.

Seperti yang tercantum dalam Kepmenkes RI No. 1087 Tahun 2010 tentang standart kesehatan dan keselamatan kerja (K3) di Rumah Sakit bahwa penyesuaian terhadap peralatan kerja SDM dikatakan sudah diterapkan apabilah telah melakukan :

1. Identifikasi dan penilaian risiko ergonomi terhadap perlatan kerja dan SDM Rumah Sakit.

2. Membuat program pelaksanaan kegiatan, mengevaluasi dan mengendalikan risiko ergonomi.

Tujuan diterapkannya K3RS adalah terciptanya cara kerja, lingkungan kerja yang sehat, aman, nyaman, dan dalam rangka meningkatkan derajat kesehatan karyawan RS. Pengetahuan K3RS

yang baik diharapkan mampu menekan angka kecelakaan kerja karena individu tersebut dapat menerapakan tindakan yang sesuai dengan pengetahuan K3 yang dimilikinya.

\section{PEMBAHASAN}

Kesehatan dan Keselamatan Kerja (K3) adalah upaya untuk memberikan jaminan keselamatan dan meningkatkan derajat kesehatan perawat atau pekerja dengan cara pencegahan kecelakaan dan penyakit akibat kerja (PAK).

Organisasi Buruh Internasional atau International Labour Organization (ILO) merupakan suatu organisasi yang menaungi permasalahan K3 di tingkat dunia. Menurut ILO pelaksanaan K3 ditujukan untuk mencegah kecelakaankerja dan penyakit yang ditimbulkan oleh suatu pekerjaan. Permasalahan K3 juga diatur oleh Organisasi Kesehatan Dunia atau World Health Organization (WHO). 
Penerapan K3 di Indonesia diatur oleh Undang- Undang Republik Indonesia Nomor 13 Tahun 2003 tentang Ketenagakerjaan, sedangkan K3 rumah sakit (K3RS) diatur oleh KEPMENKES RI Nomor 1087/MENKES/SK/VIII/2010. K3 pada umumnya bertujuan melindungi keselamatan dan kesehatan pekerja ataupun buruh dalam mewujudkan produktivitas kerja yang optimal.

Tujuan diterapkannya K3RS adalah terciptanya cara kerja, lingkungan kerja yang sehat, aman, nyaman, dan dalam rangka meningkatkan derajat kesehatan karyawan RS. Pengetahuan K3RS yang baik diharapkan mampu menekan angka kecelakaan kerja karena individu tersebut dapat menerapakan tindakan yang sesuai dengan pengetahuan K3 yang dimilikinya.Keselamatan pasien indentik dengan kualitas pelayanan, semakin baik kualitas layanan maka keselamatan pasien juga akan semakin baik.

Tujuan pengembangan program Keselamatan pasien (patient safety) di rumah sakit adalah, menciptakan budaya patient safety, memperbaiki akuntabilitas rumah sakit, melakukan pencegahan kejadian yang tidak diinginkan tidak terulang kembali .

Salah satu komponen tenaga pelayan kesehatan di rumah sakit adalah perawat. Perawat berinteraksi langsung terhadap pasien dengan intensitas yang paling tinggi dibandingkan dengan komponen yang lainnya. Keselamatan sangat dibutuhkan oleh perawat saat bekerja. Keselamatan merupakan salah satu kebutuhan dasar manusia yang harus dipenuhi.

Manajemen rumah sakit bertanggung jawab untuk membuat program manajemen risiko yang berkelanjutan untuk mengurangi dan mengidentifikasi kejadian yang tidak diinginkan dan risikorisiko keselamatan lainnya pada pasien dan staf rumah sakit. Perawat seringkali kurang peduli terhadap bahaya di tempat kerja dan dalam melakukan upaya proteksi diri meskipun perawat tahu hal tersebut dapat membahayakan keehatan dan nyawa perawat.

Perilaku perawat dalam bekerja dipandu melalui pedoman kerja. Selain standar operasional prosedur (SOP) dan standar asuhan keperawatan (SAK) sebagai pedoman perawat dalam bekerja, panduan keselamatan perawat diperlukan untuk memandu perawat berperilaku amandan selamat dalam bekerja. Oleh karena itu, protokol keamanan untuk perawat dan pasien harus diikuti dan dipraktikkan dengan baik. 
Pada hakekatnya Keselamatan dan Kesehatan Kerja (K3) merupakan suatu usaha untuk menciptakan perlindungan dan keamanan dari berbagai risiko kecelakaan dan bahaya, baik fisik, mental maupun emosional terhadap pekerja, perusahaan, masyarakat dan lingkungan.Disamping itu, keselamatan dan kesehatan kerja diharapkan dapat menciptakan kenyamanan kerja dan Keselamatan kerja yang tinggi.

\section{Pemicu penyakit karena kerja.}

Bahaya potensial yang dapat menyebabkan penyakit akibat kerja (PAK) yang terjadi di rumah sakit, umumnya berkaitan dengan :

1.faktor biologi (kuman patogen yang umumnya berasal dari pasien, seperti bakteri, viral diseases, parasitic diseases dan sebagainya)

2. faktor kimia (pemaparan dalam dosis kecil namun terus menerus seperti antiseptik pada kulit, gas anestesi pada hati, debu yang bisa menyebabkan pneumoconioses dan sebagaimya, uapserta gas beracun yang bisa mengakibatkan keracunan)

3.faktor ergonomi (Tempat kerja, alat kerja yang tidak ergonomis, langkah kerja yang salah, konstruksi yang salah hingga bisa mempunyai dampak kelelahan pada tubuh, seperti tata cara duduk, tata cara mengankat pasien)

4.faktor fisik dalam dosis kecil yang terus menerus (suhu udara panas, listrik tegangan tinggi, dan radiasi)

5.faktor psikologis ( hubungan kerja antar karyawan atau atasan serta tata cara kerja di kamar bedah, dibagian penerimaan pasien, di unit gawat darurat dan ruang perawatan.)

Penyakit karena kerja serta kecelakaan kerja dikalangan petugas kesehatan serta non kesehatan di lingkungan rumah sakit belumlah terselesaikan dengan baik, hingga berlangsung kecenderungan penambahan prevalensi.Dalam perihal ini perlu mendapatkan perhatian, sebab seseorang yang bekerja bila mengalami kecelakaan atau penyakit karena kerja tidak hanya punya pengaruh pada diri sendiri, tapi ikut produktifitas kerja mengalami penurunan dalam pemberian service kesehatan yang optimal pada pasien. 


\section{Upaya pencegahan}

1. Melakukan pencatatan kejadian Kecelakaan Akibat Kerja (KAK) sesuai dengan prosedur yang ditetapkan oleh petugas K3. Seperti yang tercantum dalam Permenaker No. 03 Tahun 1998 menyatakan bahwa pengurus atau pengusaha wajib melaporkan tiap kecelakaan yang terjadi di tempat kerja. Penyampaian laporan dapat dilakukan secara lisan sebelum dilaporkan secara tertulis.

2. Perlu dilakukan peningkatan terhadap penerapan pelayanan kesehatan kerja terutama pada pemeriksaan kesehatan khusus, pengobatan dan perawatan bagi penderita yang sakit, pemantauan lingkungan kerja serta ergonomi dan evaluasi pencatatan serta pelaporan kepada Direktur Rumah Sakit.

3. Perlu diadakan pemeriksaan kesehatan sebelum bekerja seperti pemeriksaan paru-paru, laboratorium maupun pemeriksaan secara fisik terhadap perawat IGD maupun tenaga medis yang lain.

4. Perlu diadakan kegiatan survelans kerja seperti pemetaan tempat keja berdasarkan risiko bahayanya.

5. Perlu diadakan penyesuaian terhadap peralatan kerja SDM Rumah Sakit seperti mengidentifikasi ergonomi terhadap peralatan kerja dan risiko peralatan kerjanya.

Seperti yang tercantum dalam Kepmenkes RI No. 1087 Tahun 2010 tentang standart kesehatan dan keselamatan kerja (K3) di Rumah Sakit bahwa penyesuaian terhadap peralatan kerja SDM dikatakan sudah diterapkan apabilah telah melakukan :

1. Identifikasi dan penilaian risiko ergonomi terhadap perlatan kerja dan SDM Rumah Sakit.

2. Membuat program pelaksanaan kegiatan, mengevaluasi dan mengendalikan risiko ergonomi.

Pentingnya penyesuaian peralatan kerja SDM adalah untuk menghindari Penyakit Akibat Kerja (PAK) dan Kecelakaan Akibat Kerja (KAK) yang disebabkan karena golongan ergonomi (penyakit yang disebabkan karena prinsipprinsip peralatan kerja, proses kerja dan tempat kerja) misalnya nyeri otot, kelelahan fisik, deformitas tulang, dislokasi dan kecelakaan). 


\section{PENUTUP}

Kehidupan manusia tidak pernah terlepas dari pekerjaan,apapun jenis pekerjaan selalu dilakukan dalam rangka memenuhi kebutuhan sehari-hari, mulai dari pekerjaan berisiko rendah hingga berisiko tinggi. Disamping itu pemahaman dan pelaksanaan penerapan keselamatan dan kesehatan kerja (K3) masih kurang di perhatikan oleh pekerja formal maupun informal. Pada hal faktor K3 sangat penting dan harus diperhatikan oleh pekerja dan hal ini menjadi tanggung jawab bersama, perlu adanya kerja sama antara pemerintah, perusahaan dan pekerja agar terhindar dari Kecelakaan Akibat Kerja (KAK) dan Penyakit Akibat Kerja (PAK).

Pemahaman dan pelaksanaan dalam penerapan keselamatan dan kesehatan kerja (K3) masih kurang di perhatikan oleh perawat maupun tenaga medis lainnya. Padahal faktor K3 sangat penting dan harus diperhatikan oleh perawat dan tenaga medis dan hal ini menjadi tanggung jawab bersama, perlu adanya kerja sama antara pemerintah, Rumah Sakit dan pekerja agar terhindar dari Kecelakaan Akibat Kerja (KAK) dan Penyakit Akibat Kerja (PAK).

Berdasarkan penelitian ini dapat disimpulkan Pelaksanaan dalam penerapan keselamatan dan kesehatan kerja di rumah sakit (K3RS) upaya pencegahan penyakit pada perawat sangat penting untuk dilakukan semua SDM. Keselamatan dan kesehatan kerja pada perawat hal utama yang harus kita wujudkan dilingkungan rumah sakit agar tidak terjadi insiden dan kecelakaan yang membahayakan dan merugikan pekerja, pasien, kelurga, pengunjung, dan masyarakat dilingkungan rumah sakit. 


\section{DAFTAR PUSTAKA}

Bawelle,S.C.(2013).Hubungan Pengetahuan Dan Sikap Perawat Dengan Pelaksanaan Keselamatan Pasien (Patient Safety) Di Ruang Rawat Inap RSUD Liun Kendage Tahuna. EJournal Keperawatan.1, (10):1-7

Cindy Dwi Yuliandi, Eeng Ahman. (2019). Penerapan Keselamatan Dan Kesehatan Kerja (K3)

Di Lingkungan Kerja Balai Inseminasi Buatan (BIB) Lembang. Manajerial, Vol. 18 No. 2

Liza Salawati.(Agustus 2015). Penyakit Akibat Kerja Dan Pencengahan. Jurnal Kedokteran Syiah Kuala. Volume 15 Nomor 2

Nida Dini Hanifa, Titik Respati, Yuli Susanti. (2017). Hubungan Pengetahuan dengan Upaya Penerapan K3 pada Perawat. Bandung Meeting on Global Medicine \& Health (BaMGMH), Vol. 1 No. 1

Nur Azizah, Setiawan, Gerry Silaban. (Desember 2018 - Mei 2019). Hubungan Antara Pengawasan, Prosedur Kerja Dan Kondisi Fisik Dengan Terjadinya Kecelakaan Kerja Pada Perawat Di Ruang Rawat Inap Rumah Sakit Permata Bunda Medan Tahun 2017. Jurnal Jumantik Vol. 3 No.2

Parlagutan, M.T, Pratama, M.Y. (2017). Hubungan Work Family Conflict Dengan Stres Kerja pada Perawat Wanita di Rumah Sakit Putri Hijau Medan. Jurnal Riset Hesti Medan Akper Kesdam I/BB Medan. Vol. 1, No.1

Pitoyo, J., Rudi H., \& Titis E S. (2017). Kepatuhan Perawat Menerapkan Pedoman Keselamatan Kerja Dan Kejadian Cedera Pada Perawat Instrumen Di Instalasi Bedah Sentral. Jurnal Pendidikan Kesehatan, 6(2), 65-70

Silvia Maria, Joko Wiyono ,dan Erlisa Candrawati. (2015). Kejadian Kecelakaan Kerja Perawat Berdasarkan Tindakan Tidak Aman. Jurnal Care Vol. 3, No. 2

Simamora, R. H. (2020). Pelatihan Komunikasi Efektif untuk Meningkatkan Efikasi diri Perawat dalam Pelaksanaan Identifikasi Pasien. JURNAL ILMIAH KESEHATAN MASYARAKAT: Media Komunikasi Komunitas Kesehatan Masyarakat, 12(1), 49-54. 
Simamora, R. H. (2011). ROLE CONFLICT OF NURSE RELATIONSHIP WITH PERFORMANCE IN THE EMERGENCY UNIT OF HOSPITALS RSD DR. SOEBANDI JEMBER. The Malaysian Journal of Nursing, 3(2), 23-32.

Sudarmo., Zairin N H., \& Lenie M. (2016). Faktor Yang Mempengaruhi Perilaku Terhadap Kepatuhan Penggunaan Alat Pelindung Diri (APD) Untuk Pencegahan Penyakit Akibat Kerja. Jurnal Berkala Kesehatan, 1(2), 88-95.

Widiwati Rinjani Octavia, Diana Nerawati, Ernita Sari. (APRIL 2018). Penerapan Pelayanan Kesehatan Dan Keselamatan Kerja Pada Perawat IGD Rumah Sakit Umum DR.WAHIDIN SUDIRO HUSODO MOJOKERTO Tahun 2017. Gema Kesehatan Lingkungan. Vol 16 No. 1 